\title{
Stakeholders Perception of Economics Teachers Mastery of Professional Skills in Senior Secondary Schools in Federal Capital Territory, Abuja, Nigeria
}

\author{
Ogunode Niyi. $\mathbf{J}^{1}$ \\ ${ }^{1}$ Academic Planning Unit, Federal University Wukari, Taraba State, Nigeria \\ Email:ogunodejacob@gmail.com
}

\begin{abstract}
This paper is aimed to investigate the stakeholder perception of economics teacher mastery of professional skills in senior secondary school in Federal Capital Territory, Abuja, Nigeria. The study was guided by two research questions and two hypotheses were tested. The study adopted a correlation research design. The study population comprised 150 secondary school senior economics students and 20 stakeholders within the schools system in Abaji. Stratified proportionate sampling technique was used to sample 170 respondents from the population of the study. The researchers developed one sets of instruments titled "Stakeholders perception of Economics Teacher Questionnaire (SPETQ)" was used for data collection. The instrument was subjected to face and content validation by two experts who are lecturers; two in Department of economics education university of Abuja. Cronbach alpha was employed for the reliability test and this yielded a coefficient of $0.78,0.68$ and 0.81 for the three parts of (SPETQ) and 0.78 . Pearson product moment coefficient was used in answering the research questions and t-test was used in testing the hypotheses. The findings of the study revealed among others that most economics teachers have adequate knowledge of their subject matter, good at lesson plan/lesson note writing skills, effective use of instructional aides, good evaluation skills, good at classroom management skills and marking and recording skills. also revealed that there That most economics teachers performs their job below expectation on the bases of comes to class regularly, gives enough assignment and class exercises, comes to class with his/her lesson plan, marks and records the CA and students exams on time and corrections of failed C.A and assignment in the class. Based on the findings, conclusion was drawn and it was recommended among others that government should provide training programme should be put in place by the government to refresh the economics teachers on the mastery of their professional skills. Some states in Nigeria have started on the job training for their teachers to upgrade the teachers. This should be extended to other states and the government should constant supervision of secondary to ensure that every teacher is doing its work. The principal should ensure effective instructional supervision in order to keep them at par with their foreign counterparts.
\end{abstract}

Keywords: economic, secondary school, government, Nigeria.

\section{INTRODUCTION}

Education stakeholders are group of people who have vested interest in an action of organisation. It could be an individual or group of people with an interest in the success of an organisation in delivering intended results and maintaining the viability of the organisations products and services. Stakeholders influence programmes products and services. Hence stakeholders are identified as head-teachers, teacher, pupils, parents, parents-teachers association, school management committee, board of governors and Ministry of Education (Helle, Letshego and Marinda (2011). Adebayo (2013) Parents play key roles as educational stakeholders. Parent's primary objective is the assurance that their children will receive a quality education which enables the children to lead productive rewarding lives as adult in a global society. The pupil's played a lead role in the educational process and as stakeholders is expected to participate in the process. Successful schools encourage significant participation of parents, pupils and teachers (Wilson, (2008). Job performance is another variable that could determine teacher's integrity. It is the totality of the input of the teacher towards the attainment of educational objectives. It is the act of accomplishing a given task in a school system. It could be measured through the level of teachers 
competency in subject matter, attendance to lessons, lesson note preparation, content covered, level of coverage of scheme of work, lesson preparation, monitoring of pupils work, effective supervision and the disciplinary ability of the teacher. The roles of education stakeholders are inevitable in the school system. These include an advisory position, developing strategies to train and retrain staff and leaders, turning the academic research into practical points for policy making and international cooperation among countries to promote efficiency of processes and production of reliable leaders, co- training of teachers among subAfrican and improve teachers' integrity (Brussels (2011). Based on these roles the researcher is interested in investigate the perception of education stakeholders (pupils, head-teachers and parents) to assess Economics teachers' mastery of professional skills in the teaching of Economics in senior secondary school in FCT, Nigeria.

\section{LITERATURE REVIEW}

\subsection{Concept of Secondary School}

Secondary Education is the education that children receive after primary education and before the tertiary education. Based on the 6-3-3-4 system of education, secondary education comprises six years duration, but given in two stages: a junior secondary school stage and a senior secondary school stage, each to run for three years duration. Secondary schools are directly under the state government. The State Ministry of Education handles planning, administration, supervision and other fundamental functions relating to schools. The State Ministry of Education has different departments/units that are entrusted with various functions to ensure the achievement of goals of secondary education. In addition to the departments in the Ministry of Education, there are other parastatals and regulatory agencies that are involved in secondary school administration, such as the Teaching Service Commission (TESCOM).

The National Policy on Education and the Minimum Standard for Schools specify entry requirement for teachers into junior and senior secondary schools. The policy on education recommends the minimum of a Bachelor of Education (B.Ed) or any first degree with a Postgraduate Diploma in Education (PGDE). Any qualification below this requirement is not expected to be employed to teach at this level. In the second phase of secondary school, which is senior secondary school, the policy on education recommends the minimum of a Bachelor of Education (B.Ed) or any first degree with a Postgraduate Diploma in Education (PGDE). Any qualification below this requirement is not expected to be employed to teach at this level. The reason for the emphasis on educational qualification is to enhance achievement of stated objectives. Though, a candidate seeking teaching appointment with first degree in Bachelor of Science (B.Sc) might be master of his/her discipline, this is not a sufficient condition for him/her to be considered for teaching. The skills and techniques of disseminating what he/she knows are not there. The subject matter mastery without instructional delivery technique is incomplete. The two are very important in teaching and learning.

Secondary school is an organisation which comprises personnel performing different functions to ensure the attainment of this objective. In Nigerian secondary is in two forms, the junior secondary school and the senior secondary school. Economics is one of the elective subject offered in the senior secondary school because of this, there is need for the employment of professional economics teachers in the senior secondary schools across the country. According to Bassey, and Joshua (2004) the teacher is one of the prominent and indispensable members of the school organisation team. Therefore, teacher's roles are indispensable and his integrity needs to be addressed for improved teaching and learning process. The teacher as a stakeholder is expected to possess the professional knowledge to lead the pupils in instruction. In addition to serving in an instructional capacity teacher can be a mentor, supervisor, and counsellor and community leader.

\subsection{Concept of Education Stakeholders}

Education stakeholders are group of people who have vested interest in an action of organisation. It could be an individual or group of people with an interest in the success of an organisation in delivering intended results and maintaining the viability of the organisations products and services. Stakeholders influence programmes products and services. Hence stakeholders are identified as head-teachers, teacher, pupils, parents, parents-teachers association, school management committee, board of governors and Ministry of Education (Helle, Letshego, Marinda ,2012). Brussels (2011) the roles of education stakeholders are inevitable in the school system. These include an advisory position, developing strategies 
to train and retrain staff and leaders, turning the academic research into practical points for policy making and international cooperation among countries to promote efficiency of processes and production of reliable leaders, co- training of teachers among sub-African and improve teachers' integrity.

\section{ECONOMICS TEACHERS PROFESSIONAL SKILLS}

\subsection{Knowledge of Subject Matter}

A professional economics teacher must have comprehensive knowledge of the subject matter of his/her field. An economics teacher must have in depth knowledge of every topic in the scheme of work at the secondary school level. According to Fennema and Frank (1992) teacher's knowledge of the subject matter is an indicator of teachers' teaching effectiveness. Adu (2012) in his finding on importance of Economics teachers' knowledge of subject contents, affirm that effective teaching that can lead to better achievement by the students and provide a positive attitude. This depends on the teachers' confidence and in-depth knowledge of the subject matter.

Eggen and Kauchak in Adediwura and Tayo (2007) sub-divided teachers' knowledge of subject matter into categories: knowledge of content, pedagogical content knowledge and general pedagogical knowledge. Knowledge of Mathematics and Economics itself (knowledge of subject matter) should go further than the specific content of the discipline to the knowledge of how to teach, present mathematical and economic concepts and that of selection and use of instructional media and resources (Ball and Bass ,2000). Adu, Galloway, \& Olaoye (2014) in Muijs and Reynolds (2002) posited that the teaching effectiveness of the teacher is hampered if he/she is not well versed in the contents to be taught. A teacher who has a deep understanding of the concept to be taught is more likely to use unambiguous language; their presentation is likely to be more coherent and they would offer clearer explanation than those with a weaker background, (Uya, 2011).

\subsection{Classroom Management Skills}

Adu, Galloway, \& Olaoye (2014) defines classroom management as the process of leading, directing, ordering or restraining of students in a class in a way that will lead to effective learning. One of the professional skills that an economics teachers need to be effective in the classroom is the ability to control and manage the classroom to achieve the objective of the lesson. The economics teacher must be in the control of the classroom and make it lively for students' participation. Adu, Galloway, \& Olaoye (2014) in Byrne, Hattie and Fraser (2001) observed that students will perform best in a controlled atmosphere that is conducive to academic and social needs of the students. The atmosphere in the classroom needs to be relaxed, free from threats and anxiety, non-competitive and thought provoking to allow students participate and enjoyment of the lesson. In such an atmosphere the students' interest in and attitude towards the subject taught could be enhanced. To an economics teacher achieve a classroom that is peaceful and conducive, he must introduce discipline in the classroom. Isangedighi (2007) stated that disciplined behaviour in the class is the student's ability to exercise self-control under a given classroom condition.

\subsection{Communication Ability}

One of the professional skills an economics teachers needs to deliver an effective lesson in the classroom is communication skills. An economics teacher must know how to best communicate the lesson in the way that the students will understand it. Afangideh (2001) reported that the purpose of communication in the teaching-learning process is to effect change, to produce a desired response; or to influence action contributing to the welfare of the school system. Afangideh (2001) further highlighted four dimensional objectives of communication as: to inform, to stimulate, to persuade and to remind. Adu, Galloway, \& Olaoye (2014) no subject matter can be learnt properly without the appropriate disciplines vocabulary and communication thereof, the use of the disciplines in its appropriate terms facilitates the required knowledge and understanding of whatever is being learnt. Communication may be used to mean the transfer, transmission or exchange of ideas, knowledge, beliefs, attitudes or emotion from one person or group of persons to another (Esu, 2004). Ajibade and Ehindero (2000) opined that if there is any act germane to effective teaching it is that of communicating. Teachers should strive to make their presentation as unambiguous, coherent and logical as possible. Eggen and Kauchak (2001) underlined the basic aspects of effective communication to include precise terminology, connected discourse, transition signals and emphasis. 


\subsection{Teaching Method}

Economics teachers must know the best teaching method that suit a particular topic. An economics teacher must have the ability and skills to select the best teaching method for a class he/she is planning to teach. Adu, Galloway, \& Olaoye (2014) the use of appropriate teaching method incorporates an ordered way of accomplishing an end or performing a task. Adu and Adeyanju (2013), described methods as systematic patterns to be followed in the teaching/learning process to drive home a point. Whether in, formal or informal education, teaching method effectiveness makes for retention of learnt concepts. The extent to which an instructional procedure is potent depends greatly upon its effective use by the instructor and the impression it leaves on the learner, which is usually evident in their attitude as well as performance (Obanya, 1984). Umoren (2001) in a research on methods of teaching suggested that the ability of the teacher to impart knowledge so depends greatly on the method he applies during the teaching learning process. Where the method is defective, the students stand to lose as they do not benefit from lessons. According to Uya (2008), for the teacher to be able to ensure order and enhance classroom learning, they have to possess necessary pedagogical skills which have to be systematic and methodical.

\section{STATEMENT OF PROBLEM}

Economics is one of the elective subjects offered in the Nigerian senior secondary schools. Economics has gained a lot of popularity due to its relevancy to the individual and the society in general. The parents, students and political and religious bodies which are referred to as stakeholders are all interested in the subject. Since the stakeholders' input are very important in the management of educational institution. They help in making decision from the information available to them. They are also part and pacer of the educational system. This paper deep it fit to investigate the stakeholders perception of economics teacher mastery of professional skills in senior secondary school Abaji, FCT, Nigeria.

\section{PURPOSE OF THE RESEARCH}

1. To find out the perceptions of pupils and head-teachers on the mastery of subject matter of the economics teachers?

2. To find out the perceptions of pupils and head-teachers on the job performance of the teachers?

The following research questions were generated:

\section{Research Question}

1. What are the perceptions of pupils and head-teachers on the mastery of subject matter of the economics teachers?

2. What are the perceptions of pupils and head-teachers on the job performance of the economics teachers?

\section{METHODOLOGY}

Research Design - The research design used in this study was descriptive survey.

Population - The population of this study was made up of 170 out of which 20 for principals, vice principals, H.O.D'S and 150 of senior economics students. The study sampled five senior secondary schools in Abaji Area council of F.C.T, Abuja, Nigeria.

Sample and Sampling Technique - A total of 150 Senior Secondary Schools in the Abaji area council of F.C.T, Abuja were randomly selected from the population. The sampling technique is stratified random sampling.

Research Instrument - A structured questionnaire consisting of 15 items was constructed. The questionnaire is grouped into section A and B. Section A is the respondents' background information while section $\mathrm{B}$ is the 15 itemed questions constructed on a 4 point Likert rating scale. Respondents respond as: Strongly Agreed (4), Agreed (3) Disagreed (2) strongly disagreed (1).

Validity of the Instrument - The questionnaire was validated by the researcher and other lecturer of economics department of university of Abuja who critically examined the face and content values of the instrument. They made necessary corrections for the improvement of the instrument.

Reliability of the Instrument - In this study, the test re-test method was used to determine the reliability of the instrument. Test re-test reliability is concerned with the internal consistency of an instrument. The method has the advantage of being administered twice to one group of respondents. The 15 item 
questionnaire was administered to some teachers in Abaji area council of FCT, Abuja outside the sample of the study. The two data collected were tested and correlated by applying the Pearson product moment correlation coefficient " $r$ ". A reliability coefficient of 0.90 was yielded, which shows that the research instrument has a high internal consistency.

Administration of Instrument - To ensure high percentage return of the research instrument, the researcher administered the questionnaire personally to the respondents and retrieved them instantly. This was repeated to the same respondents after one week.

Method of Data Analysis - The research questions were analyzed using the mean. For the economics principals', V.P's and H.OD'S and students' questionnaire, a modified Likert-type four-point rating scales with the numerical values of 4,3,2 and 1 assigned to the points was employed in seeking answers to the research questions. The cut-off point for the rating scale was 2.50 , obtained by dividing the sum of the numerical value by the number of scaling items.

\section{PRESENTATION OF RESULTS}

The analysis and presentation of results are organized around the research questions and null hypotheses formulated in this study.

Research Question1: What are the perceptions of students and head of department on the professional skills of the economics teachers?

Table 1: Professional skills of Economics Teachers

\begin{tabular}{|l|l|l|l|l|l|l|}
\hline N/S & ITEMS & $\begin{array}{l}\text { Strongly } \\
\text { Agreed }\end{array}$ & Agreed & Disagreed & $\begin{array}{l}\text { Strongly } \\
\text { Disagreed }\end{array}$ & TOTAL \\
\hline 1 & Mastery of subject matter & 70 & 42 & 38 & 30 & 170 \\
\hline 2 & Good at lesson plan/lesson note & 63 & 57 & 42 & 8 & 170 \\
\hline 3 & Effective use of instructional aids & 56 & 52 & 42 & 20 & 170 \\
\hline 4 & $\begin{array}{l}\text { Effective in selection of teaching } \\
\text { methods }\end{array}$ & 82 & 34 & 32 & 24 & 170 \\
\hline 5 & Good evaluation skills & 58 & 51 & 39 & 22 & 170 \\
\hline 6 & Good at classroom management skills & 66 & 52 & 28 & 24 & 170 \\
\hline 7 & Marking and recording skills & 59 & 51 & 35 & 25 & 170 \\
\hline 8 & Human relation skills & 73 & 57 & 30 & 10 & 170 \\
\hline 9 & Feedback skills & 55 & 54 & 46 & 15 & 170 \\
\hline 10 & Discipline skills & 79 & 61 & 20 & 10 & 170 \\
\hline
\end{tabular}

The data in Table 1 show the Principals, vice principals, head of department and students' mean and standard deviation ratings of 2.90 on the perception of stakeholders on the professional skills of the economics teachers in senior secondary school is above the cutoff point of 2.50. The composite means reveal that respondents were of the opinion that most economics teachers have mastery of subject matter, good at lesson plan/lesson note skills, effective use of instructional aids, good evaluation skills, good at classroom management skills, marking and recording skills, human relation skills, feedback skills and discipline skills have to a moderate extent, while the respondents also indicated that effective in selection of teaching methods was below average moderate extent. The composite mean of 2.90 indicates that the respondents accepted that the economics teachers possess the right professional skills for the teaching and learning of economics in senior secondary schools.

Question 2: What are the perceptions of pupils and head-teachers on the job performance of the economics teachers?

Table 2: Economics Teachers job performance

\begin{tabular}{|l|l|l|l|l|l|l|}
\hline N/S & ITEMS & $\begin{array}{l}\text { Strongly } \\
\text { Agreed }\end{array}$ & Agreed & Disagreed & $\begin{array}{l}\text { Strongly } \\
\text { Disagreed }\end{array}$ & TOTAL \\
\hline 1 & $\begin{array}{l}\text { Economics teacher comes to } \\
\text { class regularly. }\end{array}$ & 63 & 42 & 37 & 28 & 170 \\
\hline 2 & Economics Teachers covers the & 61 & 49 & 41 & 20 & 170 \\
\hline
\end{tabular}




\begin{tabular}{|c|c|c|c|c|c|c|}
\hline & scheme of work & & & & & \\
\hline 3 & $\begin{array}{l}\text { Economics Teachers gives } \\
\text { enough assignment and class } \\
\text { exercises }\end{array}$ & 58 & 48 & 42 & 22 & 170 \\
\hline 4 & $\begin{array}{l}\text { Economics Teachers comes to } \\
\text { class with his/her lesson plan }\end{array}$ & 62 & 43 & 33 & 30 & 170 \\
\hline 5 & $\begin{array}{l}\text { Economics Teachers marks and } \\
\text { records the CA and students } \\
\text { exams on time }\end{array}$ & 64 & 50 & 30 & 26 & 170 \\
\hline \multirow[t]{2}{*}{6} & $\begin{array}{l}\text { Economics teachers do corrections } \\
\text { of failed C.A and assignment in } \\
\text { the class }\end{array}$ & 53 & 42 & 39 & 36 & 170 \\
\hline & Total & $361[1444]$ & $274[822]$ & $222[444]$ & $162[162]$ & 2872 \\
\hline
\end{tabular}

\section{DISCUSSION}

The data in Table 2 present the mean scores of the stakeholder's perceptions on the job performance of the economics teachers in the senior secondary schools. The composite means reveal that respondents were of the opinion that most economics teachers performs their job below expectation on the bases of comes to class regularly, gives enough assignment and class exercises, comes to class with his/her lesson plan, marks and records the CA and students exams on time and corrections of failed C.A and assignment in the class. The composite mean of 2.40 indicates that the respondents rejected that most of the economics teachers perform poorly in performing their jobs in the senior secondary schools.

\section{CONCLUSION}

The study concluded that:

1. Economics Teachers have mastery of subject matter, good at lesson plan/lesson note skills, effective use of instructional aides, good evaluation skills, good at classroom management skills, marking and recording skills, human relation skills, feedback skills and discipline skills have to a moderate extent, while the respondents also indicated that effective in selection of teaching methods was below average moderate extent.

2. Economics Teachers performs their job below expectation on the bases of comes to class regularly, gives enough assignment and class exercises, comes to class with his/her lesson plan, marks and records the CA and students exams on time and corrections of failed C.A and assignment in the class.

\section{RECOMMENDATIONS}

Base on the finding:

1. Training programme should be put in place by the government to refresh the economics teachers on the mastery of their professional skills. Some states in Nigeria have started on the job training for their teachers to upgrade the teachers. This should be extended to other states.

2. The government should constant supervision of secondary to ensure that every teacher is doing its work

\section{REFERENCES}

1. Adu, E.O., Galloway, G., \& Olaoye, O. (2014). Teachers' characteristics and students' attitude towards economics in secondary schools: Students' perspectives. Mediterranean Journal of Social Sciences, 5(16), 455-462.

2. Adebayo, F, A. (2013). Stakeholders Perception of Teachers Integrity in Elementary Schools in Nigeria .Literacy Information and Computer Education Journal (LICEJ), Volume 4, Issue 4.

3. Afangideh, M. E. (2001). Communication in teaching learning process. In D. U. Umoren \& C. M. 
4. Bassey, B.A. and Joshua, M.T. (2004). Teachers' perception of student evaluation of teaching effectiveness. African Education Research Network. www/findarticles.com. Retrieved 21/03/2013.

5. Ball, D. L., \& Bass, H. (2000). Interweaving content and pedagogy in teaching and learning to teach: Knowing and using mathematics. In J. Boaler (Ed), multiple perspectives in mathematics of teaching and learning, 83-104. Westport, Conn: Ablex publishing.

6. Bryne, D. B., Hattie, D. A., \& Frazer, B. J. (2001). Students' perceptions of preferred classroom learning environment. Journal of Educational Research, 80(1), 10-16.

7. Brussels M, D, (2011). Report of the Conference of the European Network on Education Councils (EUNEC) on participation and stakeholder involvement in education policy making. www.eunec.eu. Retrieved 16/03/2013.

8. Eggen P., \& Kauchak, D. (2002). Strategies for teachers: Teaching content and thinking skills (4th ed.). In: A.A.

9. Esu, A. E. O. (2003). Teaching of social studies in primary school. In A. E. O. Esu \& E.P. Nkutidem (Eds.), Fundamental of Elementary Education. Calabar, Helino Associates.

10. Esu, A. E. O. (2004). Competences for effective teaching. In S.C. Uche \& I.O. Enukola (Eds), Professional skills for effective teaching. Aba: AAU Publishers.

11. Fennema, E., \& Franke, M. L. (1992). Teachers' knowledge and its impact. In: D. A. Grouws (Ed.) Handbook of research on mathematics teaching and learning. A project of the National Council of Teachers of Mathematics, 147-164. New York: Macmillan

12. Helle D, Letshego M, Marinda W,. (2011). Perception of knowledge of rules and respect among educators: teachers as an indicator of integrity. www.un.org/tisda South Africa. Retrieved 30/03/3013.

13. Muijs, D., \& Reynolds, D. (2002). Teachers' belief and behaviours: What really matter? Journal of classroom, interaction, 37(2), 3-15.

14. Obanya, P. A. (1984). General methods of Teaching. Lagos: Macmillan publishers Ltd.

15. Offorma, G. C. (1994). Curriculum implementation and instruction. Onitsha: Uniworld Educational publishers (Nig.) Ltd.

16. Ogbodo (2007). A handbook in teaching profession in Nigeria, 144-156. Uyo: Guidepost Publishers.

17. Udofot, M. A. (1995). Current trends of teacher Educational practices. Uyo: Imasons Educational services.

18. Nnebedum C \& Akinfolarin V, in Caleb(20170. Principals' Supervisory Techniques as Correlatesof Teachers' Job Performancein Secondary Schools in Ebonyi State, Nigeria. International Journal for Social Studies, ISSN: 2455-3220 Volume 03 Issue 10

19. Oron Local Government Area. Unpublished project, University of Uyo, Akwa Ibom State.

20. Uya, A. O. (2011). Teacher's characteristics and students' attitude towards mathematics in senior secondary of Oron Federal constituency of Akwa Ibom State. Unpublished M.Ed. Dissertation, University of Uyo. Akwa Ibom State.

21. Uya, A. O. (2008). The effects of use of computer as teaching strategy on secondary school students' achievement in trigonometry. 